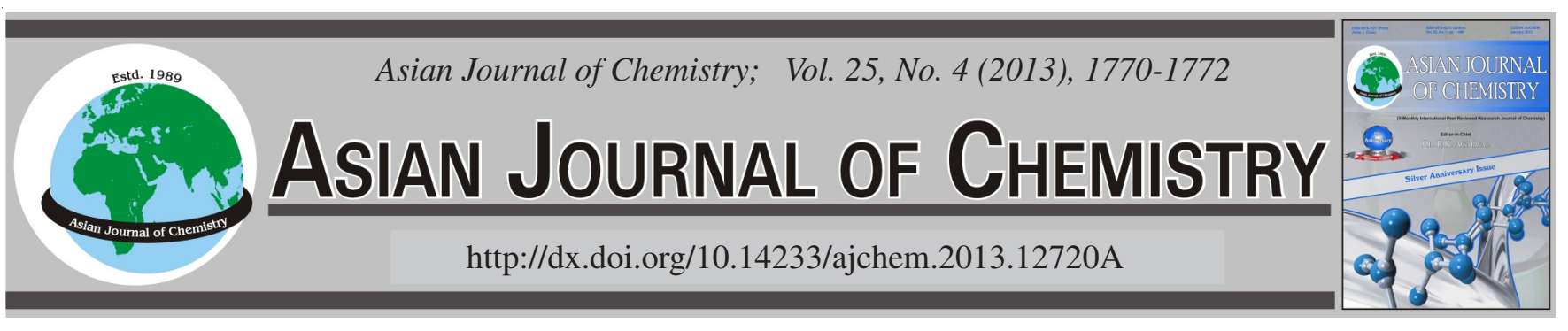

\title{
Synthesis, Characterization and Antibacterial Study of Co(II), Ni(II), Mn(II) and Cu(II) \\ Complexes Derived from 1,5-Dimethyl-4-\{[1-(3-methyl-5-oxo-1-phenyl-4,5-dihydro -1H-pyrazol-4-yl-idene)ethyl]amino\}-2-phenyl-1H-pyrazol-3(2H)-one
}

\author{
Hualing Zhu* ${ }^{*}$ Chen Chen, Junbin Wang, Zhen Wei and Yanan Bai
}

Department of Basic Science, Tianjin Agricultural College, Tianjin, P.R. China

*Corresponding author: Tel: +86 22 23781295; E-mail: zhuhualing2004@126.com

(Received: 13 September 2011;

Accepted: 3 October 2012)

AJC-12215

$\mathrm{Co}(\mathrm{II}), \mathrm{Ni}(\mathrm{II}), \mathrm{Mn}$ (II) and $\mathrm{Cu}(\mathrm{II})$ complexes derived from 1,5-dimethyl-4-\{[1-(3-methyl-5-oxo-1-phenyl-4,5-dihydro-1H-pyrazol-4-ylidene)ethyl]amino $\}$-2-phenyl-1H-pyrazol-3(2H)-one have been prepared and characterized by elemental analysis, spectroscopic data (IR and UV) and H NMR. The antibacterial activity tests of the ligand and its metal complexes at different concentrations against Escherichia coli and Bacillus subtilis were performed by using disc diffusion method. The results indicate that almost all the compounds have the activity of inhibiting the growth of the two bacteria.

Key Words: Synthesis, Characterization, Complex, Antibacterial activity.

\section{INTRODUCTION}

Due to the potential application in medicine, biology, materials and chemical industry, Schiff base and its metal complexes are paid more attention. Most of the people are interested in the researches of the synthesis and biological activities of new Schiff bases. 4-Amino antipyrine derivatives have been widely used in the analgesic ${ }^{1,2}$, antibacterial and antitumor field and chemical analysis. 4-Amino antipyrine schiff bases have showed unique properties and application in the biological, clinical, pharmaceutical and analytical fields $s^{3,4}$. Keeping in mind above biological significance of Schiff base and in continuation of our earlier work ${ }^{5}$, we report herein the preparation, characterization and anti-bacterial study of $\mathrm{Co}(\mathrm{II})$, $\mathrm{Ni}(\mathrm{II}), \mathrm{Mn}(\mathrm{II})$ and $\mathrm{Cu}(\mathrm{II})$ complexes derived from 1,5-dimethyl4-\{[1-(3-methyl-5-oxo-1-phenyl-4,5-dihydro- $1 H$ - pyrazol-4yl-idene)ethyl]amino 3 -2-phenyl-1 $H$-pyrazol-3(2H)-one.

\section{EXPERIMENTAL}

1-Phenyl-3-methyl-4-acetyl-pyrazolone-5 (HPMAP) were synthesized according to reported method ${ }^{6}$. Other chemicals obtained as reagent grade were used without further purification, IR spectra were recorded on Perkin-Elmer-1700 spectrophotometer using $\mathrm{KBr}$ disc. ${ }^{1} \mathrm{H} \mathrm{NMR}$ spectrum were recorded on FT-AC-80 spectrophotometer using TMS as internal standard.

Preparation of the ligand: The ligand was synthesized by refluxing the mixture of 1-Phenyl-3-methyl-4-acetyl- pyrazolone (25 m mol) and 4-amino antipyrine $(25 \mathrm{~m} \mathrm{~mol})$ in ethanol $(150 \mathrm{~mL})$ over a steam bath for about $7 \mathrm{~h}$, then the solution was cooled down to room temperature. After five days, pale yellow block was obtained. The block was separated, washed with ethanol and dried over $\mathrm{CaCl}_{2}$ in vacuum.

Preparation of the complexes: The complexes of $\mathrm{Co}$ (II), $\mathrm{Ni}(\mathrm{II}), \mathrm{Mn}(\mathrm{II})$ and $\mathrm{Cu}(\mathrm{II})$ have been formed by reacting ethanolic solution of appropriate metal salts with ethanolic solution of ligand in the molar ratio 1:2. The mixture was heated on water bath for $c a$. $4 \mathrm{~h}$, then the mixture were cooled under room temperature and solid coloured complexes separated out which was filtered, washed with ethanol, dried over $\mathrm{CaCl}_{2}$ in vacuum.

\section{RESULTS AND DISCUSSION}

The IR spectra data of the free ligand and its metal complexes are given in Table-1. The spectra of the ligand exhibits broad band at about $3427 \mathrm{~cm}^{-1}$ assigned to $\mathrm{v}(\mathrm{N}-\mathrm{H})$, accordingly the band at $1530 \mathrm{~cm}^{-1}$ assigned to $\delta(\mathrm{N}-\mathrm{H})$, there is also a band at $1128 \mathrm{~cm}^{-1}$ assigned to $\mathrm{v}(\mathrm{N}-\mathrm{C})$. All these bands suggest that the ligand exists in an enamine-keto form.

The brand $1623 \mathrm{~cm}^{-1}$ of the ligand is assigned to the $\mathrm{C}=\mathrm{O}$ of the antipyrine. This band disappears in the complex which suggests the ligand is decomposed when the complex is formed, the decomposed structure of the $\mathrm{Cu}$ complex is also described by the article ${ }^{7}$. The IR spectrum of the ligand also exhibits a strong and sharp band at $1672 \mathrm{~cm}^{-1}$ assigned to $\mathrm{v}(\mathrm{C}=\mathrm{O})$ 


\begin{tabular}{|c|c|c|c|c|c|c|c|c|}
\hline \multicolumn{9}{|c|}{$\begin{array}{l}\text { TABLE-1 } \\
\text { IR DATA }\left(\mathrm{cm}^{-1}\right) \text { AND UV DATA }(\mathrm{nm}) \text { OF LIGAND AND THE METAL COMPLEXES }\end{array}$} \\
\hline Type & $\mathrm{V}(\mathrm{N}-\mathrm{H})$ & $v(\mathrm{C}=\mathrm{O})(\mathrm{PMAP})$ & $\mathrm{v}(\mathrm{C}=\mathrm{O})$ (antipyrine) & $v(\mathrm{C}-\mathrm{O})$ & $\mathrm{v}(\mathrm{M}-\mathrm{O})$ & $v(M-N)$ & \multicolumn{2}{|c|}{ UV } \\
\hline Free ligand & 3427 & 1672 & 1623 & & & & 285 & 305 \\
\hline $\mathrm{Cu}$ complex & 3431 & 1606 & & 1381 & 546 & 469 & 275 & 345 \\
\hline Co complex & 3436 & 1615 & & 1385 & 545 & 468 & 285 & 355 \\
\hline $\mathrm{Ni}$ complex & 3420 & 1625 & & 1368 & 586 & 440 & 280 & 360 \\
\hline Mn complex & 3408 & 1612 & & 1327 & 608 & 491 & 285 & 350 \\
\hline
\end{tabular}

TABLE-2

COLOUR, ELEMENTAL ANALYSIS AND HNMR SPECTRAL DATA OF ALL COMPOUNDS

\begin{tabular}{|c|c|c|c|c|c|c|c|}
\hline \multirow{2}{*}{ No } & \multirow{2}{*}{ Colour } & \multicolumn{3}{|c|}{ Elemental analysis (\%): Found (calcd.) } & \multicolumn{3}{|c|}{ Chemical shifts (DMF, ppm) } \\
\hline & & $\mathrm{C}$ & $\mathrm{H}$ & $\mathrm{N}$ & $\mathrm{N}-\mathrm{H}$ & Ar-H & $\mathrm{CH}_{2} / \mathrm{CH}_{3}$ \\
\hline Free ligand & Pale yellow & $68.87(68.83)$ & $5.76(5.74)$ & $17.37(17.46)$ & 8.14 & $7.1-7.8$ & $1.0-3.8$ \\
\hline $\mathrm{Cu}$ complex & Dark Green & $58.82(58.78)$ & 4.47 (4.49) & $17.16(17.14)$ & 8.32 & $7.0-7.6$ & $0.9-2.8$ \\
\hline Co complex & Pink & $59.30(59.39)$ & $4.57(4.54)$ & $17.42(17.32)$ & 8.34 & $7.0-7.7$ & $1.1-2.8$ \\
\hline Ni complex & Green & $59.54(59.42)$ & $4.51(4.54)$ & $17.34(17.33)$ & 8.49 & $7.2-7.8$ & $1.0-3.5$ \\
\hline Mn complex & Yellow & $59.90(59.88)$ & $4.47(4.57)$ & $17.42(17.46)$ & 8.23 & 7.1-7.7 & $0.9-3.8$ \\
\hline
\end{tabular}

TABLE-3

DIAMETER DATA OF INHIBITION ZONE TO THE Schiff bases

\begin{tabular}{|c|c|c|c|c|c|}
\hline \multirow{2}{*}{ Compound } & \multirow{2}{*}{ Concentration $(\mathrm{g} / \mathrm{L})$} & \multicolumn{2}{|c|}{ Diameter (mm) } & \multicolumn{2}{|c|}{ Average diameter $(\mathrm{mm})$} \\
\hline & & Escherichia coli & Bacillus subtilis & Escherichia coli & Bacillus subtilis \\
\hline \multirow{3}{*}{ Mn complex } & 5.00 & $28.0 / 15.0 / 29.0$ & $17.0 / 14.0 / 12.0$ & 24.0 & 14.3 \\
\hline & 2.50 & $16.0 / 14.0 / 16.0$ & $19.0 / 22.0 / 25.0$ & 15.3 & 22.0 \\
\hline & 12.5 & 8.0/8.0/7.0 & 11.0/11.0/19.0 & 7.6 & 13.6 \\
\hline \multirow{3}{*}{$\mathrm{Cu}$ complex } & 5.00 & $12.0 / 11.0 / 13.0$ & $14.0 / 13.0 / 13.0$ & 12.0 & 13.3 \\
\hline & 2.50 & $10.0 / 10.0 / 11.0$ & $10.0 / 10.0 / 12.0$ & 10.3 & 10.6 \\
\hline & 1.25 & 11.0/12.0/13.0 & 13.0/13.0/ 12.0 & 12.0 & 12.6 \\
\hline \multirow{3}{*}{ Ni complex } & 5.00 & $10.0 / 10.0 / 11.0$ & $12.0 / 13.0 / 13.0$ & 10.3 & 12.6 \\
\hline & 2.50 & $10.0 / 10.0 / 11.0$ & $14.0 / 12.0 / 13.0$ & 10.3 & 13.0 \\
\hline & 1.25 & $11.0 / 12.0 / 11.0$ & 12.0/13.0/14.0 & 11.3 & 13.0 \\
\hline \multirow{3}{*}{ Co complex } & 5.00 & $11.0 / 10.0 / 10.0$ & $13.0 / 12.0 / 12.0$ & 10.3 & 12.3 \\
\hline & 2.50 & $10.0 / 12.0 / 10.0$ & 14.0/13.0/13.0 & 10.6 & 13.3 \\
\hline & 1.25 & $10.0 / 10.0 / 10.5$ & $12.0 / 13.0 / 13.0$ & 10.1 & 13.6 \\
\hline \multirow{3}{*}{ Ligand } & 5.00 & $14.0 / 9.0 / 8.0$ & $34.0 / 14.0 / 26.0$ & 10.3 & 24.6 \\
\hline & 2.50 & $14.0 / 13.0 / 12.0$ & 16.0/18.0/19.0 & 13.0 & 17.0 \\
\hline & 1.25 & $14.0 / 7.0 / 8.0$ & $16.0 / 14.0 / 16.0$ & 9.6 & 15.3 \\
\hline \multirow{3}{*}{$\begin{array}{l}\text { Amoxicillin } \\
\text { (Standard) }\end{array}$} & 5.00 & $11.0 / 11.0$ & $13.0 / 15.0$ & 11.0 & 14.0 \\
\hline & 2.50 & $10.0 / 10.0$ & $12.0 / 13.0$ & 10.0 & 12.5 \\
\hline & 1.25 & $11.0 / 11.0$ & $12.0 / 15.0$ & 11.0 & 13.5 \\
\hline
\end{tabular}

of pyrazolone, while this band suffered a downward shift by $47-66 \mathrm{~cm}^{-1}$ in the spectra of the complexes indicates that the coordination of the metal ion is through the carbonyl oxygen of pyrazolone. This is also supported by the presence of the band at $1327-1385 \mathrm{~cm}^{-1}$ assigned to $\mathrm{v}(\mathrm{C}-\mathrm{O})$ and far IR band at $545-$ $608 \mathrm{~cm}^{-1}$ assigned to $\mathrm{v}(\mathrm{M}-\mathrm{O})^{8}$. Another coordination atom is nitrogen atom which is confirmed by the appearance of band in the far IR region at $440-491 \mathrm{~cm}^{-1}$ assigned to $v(\mathrm{M}-\mathrm{N})$.

UV data of the complexes showing obvious red shift to that of the ligand indicates the formation of the complexes.

The analytical data (Table-2) of all the synthesized compounds shows that the complexes are composed by the 2:1 rate of ligand and metal iron. ${ }^{1} \mathrm{H}$ NMR spectra of the Schiff base and the complexes were recorded in the same solvent DMF. The signals at $8.14 \mathrm{ppm}$ in the ${ }^{1} \mathrm{H}$ NMR spectrum of the ligand due to the $\mathrm{O}=\mathrm{C}-\mathrm{C}=\mathrm{C}-\mathrm{N}-\mathrm{H}$ and there is no other signals of $-\mathrm{OH}$ in lower fields, which shows that the ligand exists in an enamine- keto form. Respectively, the signals suffered a downward shift in complexes, probably because the ligand decomposed with the form of the complexes. The possible structure of the ligand and the complexes are shown in Fig. 1.

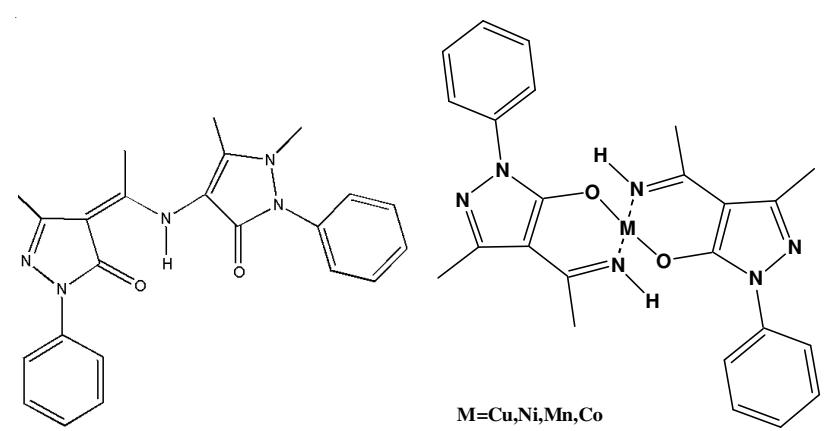

Fig. 1. Possible structure of the ligand and the metal complexes

The antibacterial activity tests (Table-3) of the ligand and the complexes at different concentrations against Escherichia coli and Bacillus subtilis were performed using disc diffusion 
method. The results indicate that almost all compounds have the activity of inhibiting the growth of the two bacteria. The values reveal that the Schiff base became less pronounced when it is coordinated to the metal ions. The biological activity of the complexes follow the order: $\mathrm{Mn}(\mathrm{II})>\mathrm{Co}(\mathrm{II})=\mathrm{Ni}(\mathrm{II})>$ $\mathrm{Cu}(\mathrm{II})$. The data show that $E$. coli was inhibited to a greater degree by the $\mathrm{Mn}$ (II) complex.

In conclusion, the Mn(II) complex prepared with the new Schiff base could reasonably be used for the treatment of some common diseases caused by Bacillus subtilis and Escherichia coli.

\section{ACKNOWLEDGEMENTS}

The authors are grateful to the Department of Basic Science, Tianjin Agricultural College of China for providing available laboratory facilities. The authors are also grateful to the Science Development Commission of Tianjin Agricultural College [No:2011N06].

\section{REFERENCES}

1. H.Q. Zhang, J.Z. Li, Y. Zhang and D. Zhang, Chin. Inorg. Chem., 24, 990 (2008).

2. V.C. Filho, A.R. Corr and Z. Vaz, IL Farmaco., 53, 55 (1998).

3. M.M. Omar, G.G. Mohamed and A.M. Hindy, J. Therm. Anal. Calorim., 2, 315 (2006)

4. P.J. Meffin, R.L. Williams, T.F. Blaschke and M. Rowland M, J. Pharm. Sci., 66, 135 (1977)

5. H.L. Zhu, L.X. Bu, Z. Wei, L. Li, Y.C. Wang and X.P. Xu, Asian J. Chem., 23, 2229 (2011).

6. B.S. Jansen, Acta Chem. Scand., 13, 1668 (1959)

7. H.L. Zhu, Z. Wang, Z. Wei, Y.N. Bai and X.P. Xv, Acta Cryst., E67, m1208 (2011).

8. L.R. Yang, C.Y. Shao, Z.L. Wang, J.T. Liu and L.F. Zhou, J. Chem. Crystallogr., 40, 58 (2010). 